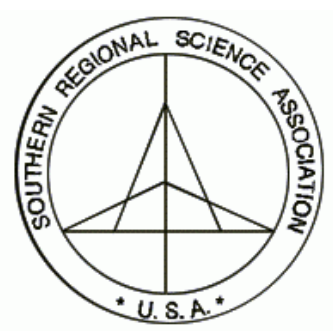

The Review of Regional Studies

Oklahoma State University

\title{
Annual Estimates of Human Capital by State: 1976-2000
}

\author{
Gary L. Hunt \\ Department of Economics, 5774 Stevens Hall, University of Maine, \\ Orono, Maine 04469-5774, e-mail: Gary.Hunt@maine.edu \\ Philip Trostel \\ Department of Economics, 5774 Stevens Hall, and Margaret Chase Smith Center for \\ Public Policy, Coburn Hall 26, University of Maine, Orono, Maine 04469-5774 \\ email:Philip.Trostel@maine.edu
}

\begin{abstract}
Aggregate and average human capital per worker in each of the 50 United States are estimated using microdata from the Annual Demographic File (ADF) and outgoing Rotation Groups (ORG) of the Current Population Survey for 1976-2000 and 1979-2000, respectively, and are compared to one another and to recent estimates from Mulligan and Sala-i-Martin $(1997,2000)$. The growthrate patterns produced substantial mixing in the state distribution of average human capital per worker and unconditional beta convergence. Aggregate human capital growth rates are dominated by workforce scale effects that strongly favor southern and western regions.
\end{abstract}

Keywords: Human capital; Regional growth; Convergence

JEL classification: J24; O49; R11 


\section{INTRODUCTION}

Several approaches have been relied on to develop empirical estimates of human capital for use in growth and convergence studies. The schooling approach uses average years of schooling (or the proportion of the population with at least some particular level of schooling) as a proxy for human capital. For example, a worker with 12 years of schooling has twice the human capital as a worker with six. As Mulligan and Sala-i-Martin $(1997,2000)$ point out, empirical analyses of economic growth in the macroeconomic growth literature in the 1990s often use the schooling approach. As they argue, there are a number of problems with this approach that can be addressed by using a labor-income approach instead. The wage approach proxies human capital stocks with estimates of the mean wage for workers with specific levels of schooling, conditional on various industries or occupations and age-gender-race characteristics. A worker with twice the conditional wage would have twice the human capital under this approach. Several studies in the regional economic growth and convergence literature (e.g., Horiba and Kirkpatrick 1979, 1981; Bellante 1979; Bellante and Dunlevy 1983) construct aggregate indexes of human capital using the wage approach.

More recent wage approaches use variants of a Mincerian (1974) log-wage equation. Mulligan and Sala-i-Martin (1997) use a truncated Mincerian approach that estimates the wages of (unskilled) workers with zero years of schooling as the constant term in a logwage equation that includes a linear schooling term. This estimate then is used as a numeraire to compute the average human capital per worker as total labor earnings per capita divided by this numeraire. Jones (2002) also employs a truncated Mincerian approach that estimates human capital per worker as the linearly parameterized schooling term in a log-wage specification. A Mincerian approach that is not truncated to schooling is utilized by Bils and Klenow (2000). Their log-wage formulation includes a quadratic in potential experience as well as a linear term in schooling. This is consistent with the original Mincerian specification and the vast empirical literature supporting the Mincerian model (Rosen 1992).

The input-aggregation approach utilizes production theory to aggregate various skilldifferentiated groups of workers into an aggregate input referred to as human capital. Mulligan and Sala-i-Martin (2000) compute an aggregate Divisia human capital index and a corresponding per-worker index for U.S. states based on a Translog aggregation. Given that their estimates indicate a Translog form is not exact for the underlying labor partition of the technology, they develop a spatial sequencing method for the optimal pairing of states in computing the Divisia index that minimizes the approximation errors. Their optimal human capital measure is referred to as the Geographic Traveling Salesman (GTS) measure.

We propose an extension of the Mincerian approach. This generalized-Mincerian approach specifies that schooling and potential experience combine in a substantially nonlinear manner to produce units of human capital. The valuation of these units is then related to the extant supply and demand conditions faced by human capital and by the 
demographic and industry characteristics of workers. The former conditions include the relative supplies of other factors, trade conditions, technical progress, and amenities that can vary spatially and temporally. These are proxied by spatial and temporal fixed effects that are possible to specify in our work because we use up to 25 years of microdata from the Current Population Survey (CPS). The demographic and industry characteristics are proxied by indicators for gender, race, ethnicity, government employment, and self-employment. The model is presented explicitly in the following section.

What contribution does this approach make relative to the other approaches outlined above? A generalized-Mincerian approach is generally preferred to the schooling and truncated Mincerian approaches because it is a labor market-based measure that incorporates variations in the productivity of schooling and experience consistently with microeconomic foundations (Hall and Jones 1999; Jones 2002) that are supported by a large body of empirical evidence (Rosen 1992). An evaluation relative to the inputaggregation approach is presented in the following section after the specifics of the generalized-Mincerian formulation are set forth. In the third section of the paper, econometric estimates of the relevant parameters are developed and presented. In the fourth section, annual state estimates of per worker and aggregate human capital based on multiple years of Annual Demographic File (ADF) and Outgoing Rotation Group (ORG) microdata samples from the CPS are presented and compared to one another and to those developed by Mulligan and Sala-i-Martin $(1997,2000)$. The estimates are then used to explore cross-sectional dispersion in per worker human capital over time across states and to test for unconditional beta convergence. In addition, the growth rates of aggregate human capital across the states and census regions are presented along with a decomposition of the growth into scale of workforce and per worker components. This decomposition provides insight into two key sources of human capital growth in the states: (1) growth in the intensive margin (average worker human capital) and (2) growth in the extensive margin (workforce scale). The final section offers a summary and conclusions.

\section{METHODOLOGY}

The hourly wage $(W)$ of a worker is modeled as the product of the stock of human capital units embodied in the worker $(h)$ and the flow price per unit of human capital $(P)$

$$
W=P h .
$$

We specify that a worker's schooling $(S)$ and experience $(E)$ combine in a nonlinear manner to produce the units of human capital embodied in the individual

$$
h=\exp [f(S, E)]
$$

where $f(S, E)$ is a nonlinear function of schooling and experience. 
The flow price of a unit of human capital $(P)$ is modeled as depending on a few demographic and employment sector characteristics such as race, ethnicity, selfemployment or government employment, and on state and year. These factors proxy for local production conditions and general supply and demand conditions across states and years and for variations in returns due to the demographic factors.

$$
P=P(x)
$$

where $\boldsymbol{x}$ is a vector of demographic and employment-sector characteristics and state and year indicator variables.

Combining Equations (1) - (3) and taking the natural logarithm, we obtain

$$
w \equiv \ln (W)=\ln (P)+f(S, E)
$$

The specific functional form for Equation (4) in the econometric estimation is

$$
w=\beta_{x}^{\prime} \boldsymbol{x}+\left(\beta_{d}^{\prime} \boldsymbol{d}+\sum \boldsymbol{\beta}_{E j}^{\prime} E^{j}+\beta_{S E} S E\right)
$$

where the flow price is modeled as $\boldsymbol{\beta}_{\mathbf{x}}{ }^{\prime} \boldsymbol{X}$ and the quantity of human capital is modeled as the terms in the parenthetical expression. The vector $\boldsymbol{x}$ includes indicator variables for race, employment sector, state, year, and a constant term. Hence, $\ln (P)$ is a specified as a linear function of these variables. Variations across space in this flow-price sub-function proxy the varying production conditions and household amenities that influence spatial marginal productivities and compensating differentials. Variations across time in this sub-function proxy aggregate supply and demand factors that influence the return to human capital from year to year.

The sub-function for quantity of human capital, $f(S, E)$, is specified as a linear combination of discrete schooling terms $\left(\boldsymbol{\beta}_{d}^{\prime} \boldsymbol{d}\right)$, a polynomial in experience $\left(\sum \boldsymbol{\beta}_{E j}^{\prime} E^{j}\right)$, and an interaction between schooling and experience $\left(\beta_{S E} S E\right)$. Each level of schooling is specified as having a discrete effect on human capital through a vector $\boldsymbol{d}$ of indicator variables that covers each level of schooling attained. This allows for substantial nonlinearity in the effects of schooling on human capital as in Hungerford and Solon (1987), Belman and Heywood (1991), and Jaeger and Page (1996). Following standard practice, experience is proxied by potential experience, which is defined as age minus years of schooling minus six. Consistent with the results reported in Murphy and Welsh (1990), the experience polynomial is specified as fourth-order. We take as a maintained hypothesis in our model that the parameters in the sub-function $f(S, E)$ that maps schooling and potential experience into quantity of human capital are spatially and temporally invariant. In other words, we are assuming that the productivity with which schooling and potential 
experience are converted into units of human capital does not vary, on average, spatially or temporally. ${ }^{1}$

Econometric estimates of the model are based on

$$
w_{i}=\beta_{0}+\beta_{x}^{\prime} \boldsymbol{x}_{i}+\boldsymbol{\beta}_{\boldsymbol{d}} \mathbf{d}_{i}+\sum \beta_{E j}^{\prime} E_{i}^{j}+\beta_{S E} S_{i} E_{i}+\varepsilon_{i}
$$

where $i$ subscripts individuals, $j=1, \ldots, 4$, and the error term $\varepsilon_{i}$ is not classical because of censoring as discussed below. Because experience profiles of wage rates for men and women are quite different, Equation (6) is estimated separately for these groups.

The estimated coefficients from Equation (6) are used to form estimates of individuals' human capital $\left(h_{i}\right)$ as follows

$$
\ln \hat{h}_{i}=\hat{\boldsymbol{\beta}}_{\mathbf{d}}^{\prime} \boldsymbol{d}_{i}+\sum \hat{\beta}_{E j}^{\prime} E_{i}^{j}+\hat{\beta}_{S E}, E_{i}
$$

The numeraire value for human capital is thus zero (natural log scale) for someone with no education and experience. Aggregate human capital in each state in each year $\left(H_{k, l}\right)$ is simply the weighted sum of individuals' human capital in the state. ${ }^{2}$

We use data from the 1977-2001 ADF and 1979-2000 ORG microdata samples from the CPS to estimate Equations (6) and (7). ${ }^{3,4}$ Earnings and hours of work in the ADF refer to the previous year. Thus, from this file we can estimate human capital stocks over the years 1976 through 2000. Earnings and hours in ORG refer to the current week. Although three years are lost using the ORG data, they have the advantage of representing a much larger sample as well as being based on current rather than retrospective information. The samples are civilian workers above the age of 16. Thus, $\hat{H}_{k, 1}$ estimates only employed human capital. There are 1,699,377 observations in the ADF sample yielding an average of 1,360 observations in each state-year cell and 3,701,507 observations in the outgoing rotations sample giving an average of 3,365 observations in each state-year cell.

A couple of complications arise in these data. Perhaps the most important complication comes from the change in the schooling variable in 1992. Prior to 1992, schooling is

\footnotetext{
${ }^{1}$ The average individual is assumed to be as capable in creating human capital units from schooling and experience in any state and during any year. Given that we only observe the state in which an individual is working and do not observe the state(s) in which an individual acquired his or her schooling, it is not feasible to determine whether state of acquisition matters. Similarly, the data do not allow us to determine whether the year of acquisition matters.

${ }^{2}$ It is important to weight $h_{i}$ because average sampling weights in the CPS differ considerably across states (the smaller states are oversampled).

${ }^{3}$ We cannot use years prior to 1977 because of incomplete data on state of residence.

${ }^{4}$ We use the CPS Utilities from the Unicon Research Corporation.
} 
measured as completed years of formal education up to 18 years. From 1992 onwards, schooling is mainly a credential-based measure. That is, schooling is measured as the highest education credential received (high school diploma, some college, two-year vocational degree, etc.). This problem, however, is somewhat mitigated by using dummy variables for each level of schooling. The two measures do not have to be conformable to estimate the direct impact of schooling on wages across pre- and post-1992 years. ${ }^{5}$ This does, however, introduce the possibility that the estimated rate of return beyond high school is different over these two periods. Moreover, education credentials have to be converted to years of education to calculate potential experience. ${ }^{6}$

A minor complication arises from some top coding (and even some bottom coding in a couple of years) of measured earnings in the CPS. Although failure to account for this only minimally affects the results, we address this problem by estimating Equation (6) as a maximum-likelihood interval regression. These estimates are reported in Table 1. The marginal returns implied by these estimates are given in the Appendix Table. The variation in the marginal rate of return to each year of schooling is consistent with that reported by Hungerford and Solon (1987), Belman and Heywood (1991), and Jaeger and Page (1996).

Recently, Mulligan and Sala-i-Martin (2000) presented an input-aggregation approach for estimating human capital for states that differs from our approach. In their approach, a Divisia Index is created for each state for selected decennial census years. The inputs for this index are the shares of a state's workforce by six exhaustive educational attainment levels and the corresponding wage bills. Hence, their index of human capital by state is an aggregate of the inputs of workers from these six educational attainment levels.

Any aggregation assumes an underlying technology characterized by (non)homotheticity, homogeneity, elasticities of complementarity among the inputs, and a structure related to technical change. The Divisia is an exact index for a Translog technology; however, the authors note that a Translog functional form is rejected with U.S. data. Therefore, the Translog becomes a second-order approximation to the

\footnotetext{
5 Another difference is that there are 19 schooling levels prior 1992, but only 16 schooling levels since 1992. Five of these levels overlap both periods $(0,9,10,11$, and 12 years of education). Thus, there are only four schooling dummies that are in both periods. In response to a referee, we tested whether these two sets of education measures could be mapped into a common set of dummy variables. The implied restrictions, in the context of estimating Equation (6) are rejected at p-values smaller than 0.0000 .

6 The conversion to years of schooling is as follows: grades $1-4=2.5$; grades $5-6=5.5$; grades 7$8=7.5$; high school diploma $=12$; some college and vocational and academic associate's degrees $=14$; bachelor's degree $=16$; master's, professional, and doctoral degrees $=18$. This conversion is consistent with that suggested by Jaeger (1997). This conversion yields a handful of observations with $E_{i}<-2$ that are dropped from the sample. All other instances of negative potential experience (a very small percentage) are converted to zero.
} 
TABLE 1

Maximum Likelihood Interval Regression Estimates of the Generalized Mincerian Equations

\begin{tabular}{|c|c|c|c|c|}
\hline \multirow[b]{2}{*}{ Variable } & \multicolumn{2}{|c|}{ Annual Demographic File } & \multicolumn{2}{|c|}{ Outgoing Rotations Groups } \\
\hline & Women & Men & Women & Men \\
\hline $\mathrm{D}_{1}$ & 0.187 & 0.164 & 0.341 & 0.247 \\
\hline $\mathrm{D}_{2}$ & 0.332 & 0.306 & 0.379 & 0.285 \\
\hline$D_{1-4}$ & 0.337 & 0.369 & 0.317 & 0.311 \\
\hline $\mathrm{D}_{3}$ & 0.328 & 0.348 & 0.360 & 0.342 \\
\hline $\mathrm{D}_{4}$ & 0.405 & 0.435 & 0.461 & 0.427 \\
\hline $\mathrm{D}_{5}$ & 0.468 & 0.517 & 0.483 & 0.504 \\
\hline $\mathrm{D}_{5-6}$ & 0.485 & 0.570 & 0.465 & 0.505 \\
\hline $\mathrm{D}_{6}$ & 0.505 & 0.576 & 0.531 & 0.552 \\
\hline $\mathrm{D}_{7}$ & 0.583 & 0.652 & 0.582 & 0.647 \\
\hline $\mathrm{D}_{7-8}$ & 0.604 & 0.735 & 0.612 & 0.676 \\
\hline $\mathrm{D}_{8}$ & 0.654 & 0.763 & 0.655 & 0.734 \\
\hline $\mathrm{D}_{9}$ & 0.716 & 0.842 & 0.695 & 0.797 \\
\hline $\mathrm{D}_{10}$ & 0.796 & 0.934 & 0.769 & 0.878 \\
\hline $\mathrm{D}_{11}$ & 0.851 & 1.002 & 0.826 & 0.942 \\
\hline $\mathrm{D}_{12 \text { - No Diploma }}$ & 0.924 & 1.048 & 0.854 & 0.969 \\
\hline $\mathrm{D}_{12}$ & 1.048 & 1.199 & 0.993 & 1.099 \\
\hline $\mathrm{D}_{13}$ & 1.167 & 1.298 & 1.100 & 1.190 \\
\hline $\mathrm{D}_{\text {Some College }}$ & 1.220 & 1.386 & 1.150 & 1.254 \\
\hline $\mathrm{D}_{14}$ & 1.264 & 1.380 & 1.206 & 1.275 \\
\hline $\mathrm{D}_{15}$ & 1.356 & 1.430 & 1.272 & 1.319 \\
\hline$D_{\text {Assoc. Degree - Voc. }}$ & 1.317 & 1.397 & 1.263 & 1.294 \\
\hline $\mathrm{D}_{\text {Assoc. Degree - Acad. }}$ & 1.373 & 1.458 & 1.288 & 1.323 \\
\hline $\mathrm{D}_{16}$ & 1.489 & 1.653 & 1.430 & 1.536 \\
\hline$D_{\text {Bachelor's Degree }}$ & 1.601 & 1.741 & 1.534 & 1.613 \\
\hline$D_{17}$ & 1.583 & 1.672 & 1.522 & 1.568 \\
\hline $\mathrm{D}_{18}$ & 1.822 & 1.923 & 1.755 & 1.772 \\
\hline$D_{\text {Master's Degree }}$ & 1.726 & 1.803 & 1.652 & 1.681 \\
\hline$D_{\text {Professional Degree }}$ & 2.033 & 2.256 & 1.880 & 1.902 \\
\hline $\mathrm{D}_{\text {Doctorate }}$ & 1.982 & 2.076 & 1.870 & 1.885 \\
\hline $\mathrm{E} \cdot 10$ & 0.711 & 0.964 & 0.677 & 0.880 \\
\hline $\mathrm{E}^{2} \cdot 10^{2}$ & -0.253 & -0.265 & -0.250 & -0.252 \\
\hline $\mathrm{E}^{3} \cdot 10^{3}$ & 0.045 & 0.036 & 0.045 & 0.036 \\
\hline $\mathrm{E}^{4} \cdot 10^{4}$ & -0.003 & -0.002 & -0.003 & -0.002 \\
\hline$S \cdot E \cdot 10^{2}$ & -0.082 & -0.095 & -0.074 & -0.097 \\
\hline Black & -0.069 & -0.186 & -0.056 & -0.178 \\
\hline Hispanic & -0.073 & -0.136 & -0.085 & -0.152 \\
\hline Other Race & -0.045 & -0.130 & -0.066 & -0.143 \\
\hline Govt. Employment & 0.048 & -0.041 & 0.028 & -0.015 \\
\hline Self Employment & -0.561 & -0.369 & & \\
\hline $\mathrm{N}$ & 804,458 & 894,919 & $1,766,330$ & $1,935,177$ \\
\hline $\mathrm{N}$ with top-coded w & 1,698 & 13,522 & 5,406 & 46,872 \\
\hline $\operatorname{LR} \chi^{2}$ & 398,742 & 436,427 & $1,215,791$ & $1,367,433$ \\
\hline
\end{tabular}


underlying technology. The authors reason from this result that the Divisia Index aggregate that they refer to as human capital will be more accurate if the economies that are processed in a pairwise fashion in computing the index are as "close together" as possible. 7 This brings up the issue of which states are most appropriate to "chain" together in computing the index, given the objective of minimizing approximation errors. Mulligan and Sala-i-Martin (2000) propose a method to decide this empirically, and they compute the Divisia Index aggregate of human capital using this method, which they refer to as the Geographic Traveling Salesman (GTS). We compare our estimates to their GTS estimates below.

The main advantages that Mulligan and Sala-i-Martin (2000) indicate for their Divisia Index-GTS measure are twofold. First, it eliminates the assumption in labor income-based measures, such as ours and theirs in previous work, that the lowest observed category of education-experience is perfectly substitutable in production for all other categories. $^{8}$ Second, it avoids the problem induced by non-neutral technical change that changes the relative productivities of workers with differing skill levels over time.

As pointed out above, the numeraire in our model is a worker without measured schooling or experience, and this type of worker is implicitly assumed to be perfectly substitutable for all others. ${ }^{9}$ This does not appear to be an important drawback given the empirical results reported by Mulligan and Sala-i-Martin (1997) and the estimates developed by Greenwood, Hunt, and Kohli (1997) that indicate that the quantity elasticities of inverse input demand between unskilled labor and seven other skill groups of labor are very similar in value, always being about 0.06 or less in magnitude. These latter

\footnotetext{
${ }^{7}$ The assumption that a Translog technology, implied by the Divisia Index, is only approximately correct in this application (in distinction to being "exact") means that the human capital measure (i.e., the Divisia Index aggregate) is being created through a second-order flexible functional form approximation. The approximation is more accurate if the data pairs required for its computation are close to the expansion point for the approximation.

${ }^{8}$ The idea of "perfect substitutability" in this context is as follows. The wage of the lowest-skilled worker (the numeraire) is the fixed unit of measure for computing the human capital of higherskilled workers. So, the human capital of higher-skilled workers is just a "blow up" of the lowestskilled worker's wage. For example, let there be two groups of workers, lower-skilled (numeraire) and higher-skilled. Let the wage observed for the former in a given year be $W L=10$ and for the latter $W H=50$. The wage ratio, $W H / W L$, is 5 ; and this represents the measure of human capital attributed to the higher-skill worker. For this method of "blowing up" the lowest skilled worker's wage to compute the human capital of other workers to be consistent, it must be assumed that any variation in the mix of lower and higher skilled workers has no impact on their relative wages. In terms of the Hicksian quantity elasticities of inverse factor demands, this implies that variations in relative quantities of such workers have no effects on relative factor prices (wages). In terms of the Allen-Uzawa direct factor demands, it implies that variations in relative prices (wages) have very large (infinite) effects on relative factor quantities. Evidence will be provided below that the relevant Hicksian elasticity measures are very close to zero, which implies that this assumption of "perfect substitutability" is not problematic.

${ }^{9}$ The numeraire is a worker with zero years of schooling and experience residing in Maine in 1979.
} 
estimates are based on an aggregate area technology that counts nine inputs and is specified with a semiflexible functional form whose estimates globally meet all regularity requirements. ${ }^{10}$

Therefore, both the prior work of Mulligan and Sala-i-Martin (1997) and the estimates developed by Greenwood, Hunt, and Kohli (1997) support the conclusion that the relative quantities of very low-skill labor have almost no quantitatively significant effect on relative wages. This is what one would expect if the various types of labor were close to being perfect substitutes in production.

A potential drawback of the Mulligan and Sala-i-Martin (2000) measure is that it is based on the assumption of separability of labor and capital in the technology. The empirical results reported by Greenwood, Hunt, and Kohli (1997) indicate that this is a less reasonable restriction than the substitutability one discussed above. Our approach incorporates spatial fixed effects to proxy for production conditions, which include varying amounts of capital and localized inputs. These fixed effects also proxy for the compensating variations in wages expected due to spatial variations in production and consumption amenities (Roback 1982; Beeson and Eberts 1989). The substantial number of years in our samples permits us to get relatively good estimates of these effects. Thus, our approach is less restrictive both in terms of the assumption of separability of labor and other inputs and in terms of the role of various local conditions of production.

One of the advantages suggested by Mulligan and Sala-i-Martin (2000) for their Divisia-Index approach is that it accounts for the non-neutral effects of technical change. It is possible to add a time trend to the Translog share equations to proxy technical change. However, with the apparent cross-sectional nature of their data, it is unclear how they accomplished this. Our approach includes dummies for each year, which captures the Hicks-neutral technical change and any neutral effects on marginal labor products as a result of, for example, cohort effects and trade.

In summary, our generalized Mincerian approach is based on specific microeconomic foundations of wage determination that have a large amount of empirical support. The effects of both schooling and potential experience are incorporated, in contrast to Mulligan and Sala-i-Martin (2000), who include only schooling. The implicit assumptions in our approach concerning substitutability within the labor partition of the technology do not seem unwarranted. Furthermore, the numerous years of cross-sectional microdata employed in the estimation permit good controls for spatial fixed effects that proxy for the impacts of non-labor inputs and other production and consumption conditions on wages. The controls for annual fixed effects permit us to estimate a com-

${ }^{10}$ See Table 9 in Greenwood, Hunt, and Kohli (1997) where quantity elasticities of inverse demand (derived from the corresponding Hicksian elasticities of complementarity) are reported for eight skill-differentiated labor inputs and capital input. These estimates are developed with a Symmetric Normalized Quadratic semiflexible functional form using maximum likelihood estimation and 1990 decennial census microdata across 121 U.S. metropolitan areas. The estimated function is globally concave and satisfies monotonicity requirement at all sample data points. 
mon nonlinear time trend in hourly wages. However, we cannot account for non-neutral effects on wages of time varying factors. This also seems to characterize Mulligan and Sala-i-Martin’s (2000) Divisia Index-GTS approach.

We therefore believe that our approach is a useful addition to that developed by Mulligan and Sala-i-Martin (2000). A comparison of results presented below suggests a substantial degree of commonality in the information content of the two different methods.

\section{STATE ESTIMATES OF HUMAN CAPITAL: 1976-2000}

\subsection{Average Human Capital Per Worker and Its Growth}

Table 2 presents estimates of average human capital per worker for each the 50 United States for selected years based on the ADF and the ORG. ${ }^{11}$ The estimates are in constant 1979 dollars. The total number of state-specific estimates from the ADF data is 1,250 ( 50 states $\times 25$ years). The corresponding number from the ORG data is 1,100 (50 states $\times 22$ years $)$

As expected, the two sets of estimates are highly correlated. The correlation coefficient is 0.96 for the 1,100 observations in common ( 50 states for the 22-year period 19792000). The average values over these 1,100 common observations are 6.37 for the ADFbased measure of per-worker human capital by state and 5.59 for the ORG-based measure. The ADF-based measure is approximately 12 percent higher on average. The ADF estimates also vary somewhat more than the ORG estimates. The standard deviation across the 1,100 common observations is 0.496 for the ADF-based measure, compared to 0.325 for the ORG-based measure.

Table 3 presents state rankings of estimated average human capital per worker for each of the 50 states for selected years based on the ADF and the ORG datasets. In addition, rankings reported by Mulligan and Sala-i-Martin (2000) are presented for 1980 and 1990. A value of one indicates the highest ranked state, and a value of 50 indicates the lowest ranked state.

The Spearman rank-order correlation coefficients between the ADF- and ORG-based state rankings for each year in common across the two samples are all at least 0.79 , thereby indicating the similarity of ordinal information content produced by the two alternative datasets. Spearman rank correlations between the state rankings from our ADF and ORG estimates and from the Mulligan and Sala-i-Martin $(1997,2000)$ studies using GTS are in the 0.65 to 0.84 range. This indicates that our estimates of average human capital per worker for states and years have a substantially common ordinal

11 Estimates for all years 1976-2000 (Annual Demographic File) and 1979-2000 (Outgoing Rotation Groups File) are available upon request. 
TABLE 2

Estimated Human Capital per Worker by State for Selected Years and Alternative CPS Data Sets

\begin{tabular}{|c|c|c|c|c|c|c|c|c|}
\hline & \multicolumn{4}{|c|}{$\begin{array}{l}\text { CPS: Annual Demographic } \\
\text { Files (March) }^{\mathrm{a}}\end{array}$} & \multicolumn{4}{|c|}{$\begin{array}{c}\text { CPS: Outgoing Rotation } \\
\text { Groups }\end{array}$} \\
\hline & 1976 & 1980 & 1990 & 2000 & 1979 & 1980 & 1990 & 2000 \\
\hline \multicolumn{9}{|c|}{ New England Division } \\
\hline Maine & 5.505 & 5.645 & 6.112 & 6.886 & 5.098 & 5.088 & 5.466 & 5.941 \\
\hline New Hampshire & 5.983 & 5.951 & 6.513 & 7.129 & 5.232 & 5.293 & 5.612 & 6.084 \\
\hline Vermont & 5.675 & 5.879 & 6.325 & 7.052 & 5.249 & 5.207 & 5.553 & 5.991 \\
\hline Massachusetts & 5.862 & 5.928 & 6.523 & 7.296 & 5.181 & 5.283 & 5.700 & 6.349 \\
\hline Rhode Island & 5.656 & 5.612 & 6.194 & 7.043 & 5.137 & 5.097 & 5.460 & 6.181 \\
\hline Conn & 5.955 & 6.053 & & 7.438 & 5.342 & 5.436 & & 6.298 \\
\hline \multicolumn{9}{|c|}{ Middle Atlantic Di } \\
\hline New York & 5.942 & 5.999 & 6.431 & 7.209 & 5.334 & 5.335 & 5.666 & 6.162 \\
\hline New & 868 & 5.877 & & 7.283 & 295 & 5.312 & 5.698 & 6.287 \\
\hline Penn & 5.708 & 5.903 & 6.228 & 7.053 & 218 & 5.236 & 41 & 6.063 \\
\hline \multicolumn{9}{|l|}{ East North Centra } \\
\hline Ohio & 5.761 & 5.815 & 6.209 & 6.881 & 5.188 & 5.201 & 5.466 & 5.982 \\
\hline & 5.751 & 5.547 & 5.923 & 6.950 & 5.027 & 5.063 & 5.386 & 6.009 \\
\hline & 5.787 & 5.867 & 6.412 & 7.024 & 5.251 & 5.252 & 5.598 & 6.001 \\
\hline Mich & 5.763 & 5.882 & 6.250 & 7.016 & 5.151 & 5.240 & 5.523 & 6.006 \\
\hline Wisce & 5.623 & 5.732 & 6.331 & 6.885 & 5.071 & 5.131 & 5.494 & 5.934 \\
\hline \multicolumn{9}{|c|}{ West North Central Division } \\
\hline Minnesota & 5.691 & 5.736 & 6.212 & 7.111 & 5.190 & 5.135 & 5.552 & 6.163 \\
\hline Iowa & 5.608 & 5.719 & 6.086 & 6.906 & 5.018 & 5.092 & 5.467 & 5.953 \\
\hline Missol & 5.689 & 5.722 & 6.138 & 6.983 & 5.179 & 5.206 & 5.416 & 6.110 \\
\hline North & 5.432 & 5.626 & 6.132 & 6.533 & 4.992 & 5.073 & 5.534 & 5.886 \\
\hline South I & 5.420 & 5.415 & 6.080 & 6.719 & 4.920 & 4.984 & 5.300 & 5.924 \\
\hline Nebraska & 5.618 & 5.635 & 6.178 & 6.722 & 4.972 & 5.107 & 5.427 & 5.844 \\
\hline Kansas & 5.731 & & & 6.981 & 5.106 & 5.208 & 5.561 & 5.935 \\
\hline \multicolumn{9}{|l|}{ South Atlantic Div } \\
\hline Delawa & 058 & & & 6.87 & & & & 6.057 \\
\hline Mar & 6.070 & & & & & & & 43 \\
\hline & & & & & & & & 219 \\
\hline West & 5.827 & 5.651 & & 6.554 & 106 & 5.158 & 5.523 & 5.855 \\
\hline North & 5.320 & 5.732 & 6.042 & 6.750 & 4.988 & 5.047 & 5.414 & 5.881 \\
\hline Soutl & 5.329 & 5.531 & 6.102 & 6.830 & 4.897 & 5.031 & 5.380 & 5.886 \\
\hline Georgia & 5.476 & 5.684 & 6.145 & 6.968 & 5.046 & 5.104 & 5.430 & 5.873 \\
\hline Florida & 5.674 & 5.773 & 6.161 & 6.972 & 5.091 & 5.102 & 5.418 & 5.945 \\
\hline \multicolumn{9}{|l|}{ East South Centra } \\
\hline Kentucky & 528 & 5.605 & 5.928 & 6.711 & .074 & 5.013 & 5.325 & 5.842 \\
\hline Tennessee & 5.427 & 5.617 & 5.991 & 6.780 & 4.962 & 5.054 & 5.378 & 5.846 \\
\hline Alabam & 5.483 & 5.598 & 5.958 & 6.747 & 5.107 & 5.069 & 5.420 & 5.921 \\
\hline Mississippi & 5.320 & 5.625 & 5.870 & 6.791 & 4.946 & 5.048 & 5.287 & 5.802 \\
\hline
\end{tabular}




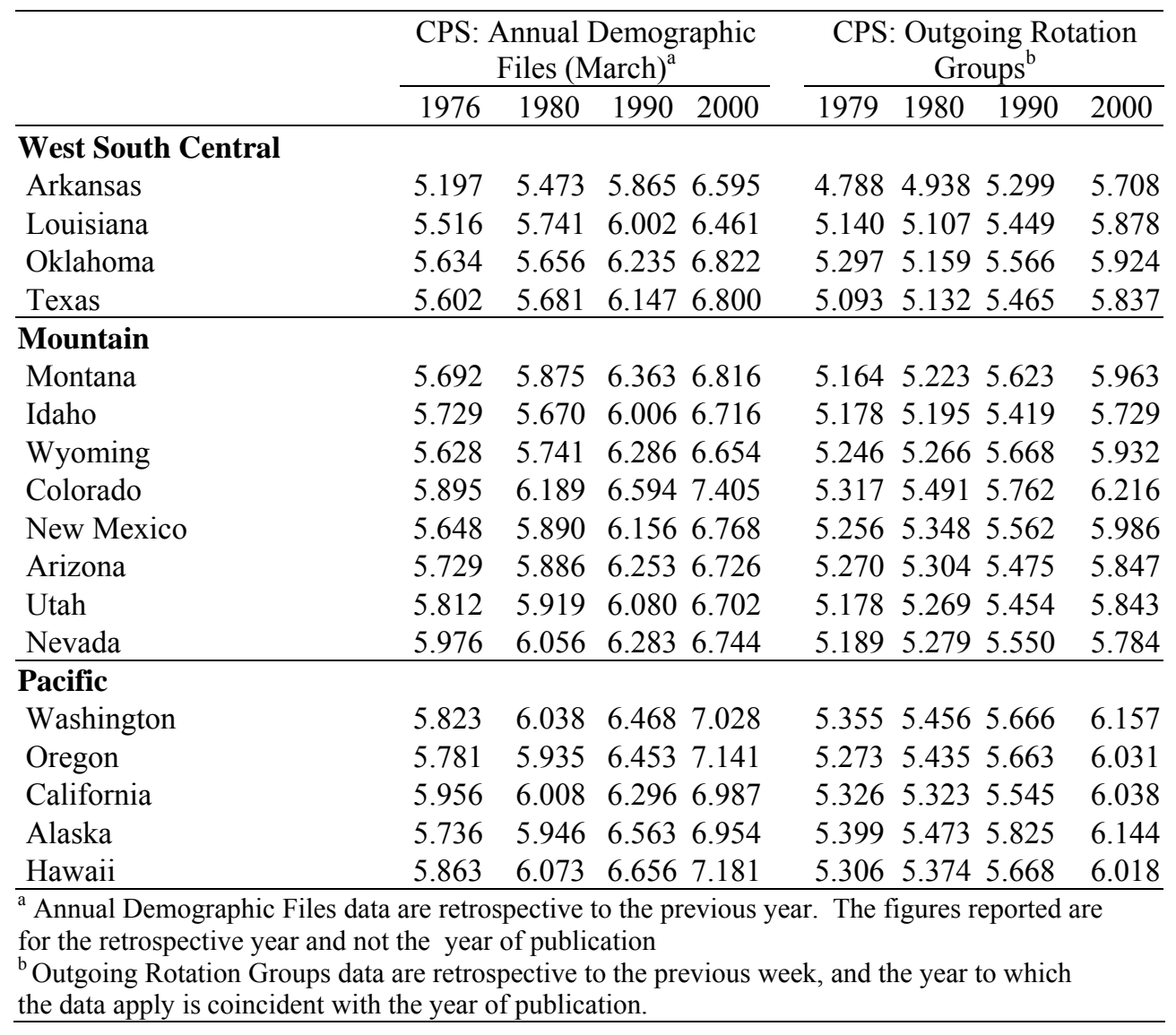


TABLE 3

State Rankings of Estimated Human Capital per Worker for

Selected Years and Alternative Data Sets

\begin{tabular}{|c|c|c|c|c|c|c|c|c|c|c|}
\hline & \multicolumn{4}{|c|}{$\begin{array}{l}\text { CPS: Annual Demographic } \\
\text { Files (March) }\end{array}$} & \multicolumn{4}{|c|}{$\begin{array}{c}\text { CPS: Outgoing Rotation } \\
\text { Groups }\end{array}$} & \multicolumn{2}{|c|}{$\begin{array}{l}\text { Mulligan and } \\
\text { Sala-i -Martin }\end{array}$} \\
\hline & 1977 & 1980 & 1990 & 2000 & 1979 & 1980 & 1990 & 2000 & 1980 & 1990 \\
\hline \multicolumn{11}{|c|}{ New England Division } \\
\hline Maine & 41 & 39 & 36 & 26 & 35 & 40 & 31 & 28 & 31 & 23 \\
\hline New Hampshire & 3 & 10 & 7 & 10 & 19 & 14 & 14 & 13 & 37 & 22 \\
\hline Vermont & 29 & 20 & 15 & 13 & 17 & 25 & 19 & 22 & 32 & 24 \\
\hline Massachusetts & 11 & 13 & 6 & 5 & 24 & 15 & 4 & 1 & 3 & 1 \\
\hline Rhode Island & 31 & 44 & 27 & 14 & 31 & 38 & 33 & 7 & 39 & 27 \\
\hline Connecticut & 6 & 4 & 3 & 1 & 5 & 4 & 2 & 3 & 6 & 2 \\
\hline \multicolumn{11}{|c|}{ Middle Atlantic Division } \\
\hline New York & 7 & 8 & 11 & 7 & 6 & 9 & 9 & 9 & 13 & 7 \\
\hline New Jersey & 9 & 21 & 5 & 6 & 11 & 11 & 5 & 4 & 11 & 3 \\
\hline Pennsylvania & 24 & 16 & 24 & 12 & 20 & 22 & 23 & 14 & 29 & 21 \\
\hline \multicolumn{11}{|c|}{ East North Central Division } \\
\hline Ohio & 18 & 24 & 26 & 28 & 23 & 27 & 30 & 24 & 25 & 25 \\
\hline Indiana & 19 & 47 & 48 & 24 & 41 & 43 & 44 & 19 & 40 & 38 \\
\hline Illinois & 15 & 23 & 12 & 16 & 15 & 20 & 15 & 21 & 22 & 10 \\
\hline Michigan & 17 & 19 & 21 & 17 & 29 & 21 & 25 & 20 & 20 & 26 \\
\hline Wisconsin & 35 & 30 & 14 & 27 & 39 & 33 & 27 & 30 & 33 & 29 \\
\hline \multicolumn{11}{|c|}{ West North Central Division } \\
\hline Minnesota & 26 & 29 & 25 & 11 & 21 & 31 & 20 & 8 & 21 & 14 \\
\hline Iowa & 37 & 33 & 39 & 25 & 42 & 39 & 29 & 26 & 38 & 39 \\
\hline Missouri & 27 & 32 & 33 & 19 & 25 & 26 & 42 & 12 & 35 & 31 \\
\hline North Dakota & 44 & 41 & 34 & 49 & 43 & 41 & 24 & 35 & 28 & 35 \\
\hline South Dakota & 46 & 50 & 40 & 42 & 48 & 49 & 48 & 32 & 36 & 46 \\
\hline Nebraska & 36 & 40 & 28 & 41 & 45 & 35 & 38 & 43 & 19 & 19 \\
\hline Kansas & 21 & 25 & 16 & 20 & 34 & 24 & 18 & 29 & 23 & 13 \\
\hline \multicolumn{11}{|c|}{ South Atlantic Division } \\
\hline Delaware & 2 & 9 & 35 & 29 & 1 & 19 & 36 & 15 & 8 & 28 \\
\hline Maryland & 1 & 6 & 10 & 3 & 2 & 6 & 13 & 2 & 14 & 5 \\
\hline Virginia & 28 & 14 & 23 & 4 & 16 & 12 & 6 & 5 & 17 & 8 \\
\hline West Virginia & 12 & 38 & 37 & 48 & 33 & 30 & 26 & 40 & 34 & 41 \\
\hline North Carolina & 49 & 31 & 42 & 37 & 44 & 46 & 43 & 37 & 47 & 42 \\
\hline South Carolina & 47 & 48 & 38 & 30 & 49 & 47 & 45 & 36 & 48 & 44 \\
\hline Georgia & 43 & 34 & 32 & 22 & 40 & 36 & 37 & 39 & 42 & 32 \\
\hline Florida & 30 & 26 & 29 & 21 & 37 & 37 & 41 & 27 & 30 & 30 \\
\hline \multicolumn{11}{|c|}{ East South Central } \\
\hline Kentucky & 39 & 45 & 47 & 44 & 38 & 48 & 47 & 45 & 46 & 45 \\
\hline Tennessee & 45 & 43 & 45 & 35 & 46 & 44 & 46 & 42 & 43 & 40 \\
\hline Alabama & 42 & 46 & 46 & 38 & 32 & 42 & 39 & 34 & 41 & 37 \\
\hline Mississippi & 48 & 42 & 49 & 34 & 47 & 45 & 50 & 47 & 44 & 48 \\
\hline
\end{tabular}




\begin{tabular}{|c|c|c|c|c|c|c|c|c|c|c|}
\hline & \multicolumn{4}{|c|}{$\begin{array}{c}\text { CPS: Annual Demographic } \\
\text { Files (March) }\end{array}$} & \multicolumn{4}{|c|}{$\begin{array}{l}\text { CPS: Outgoing Rotation } \\
\text { Groups }\end{array}$} & \multicolumn{2}{|c|}{$\begin{array}{l}\text { Mulligan and } \\
\text { Sala-i -Martin }^{\mathrm{a}}\end{array}$} \\
\hline & 1977 & 1980 & 1990 & 2000 & 1979 & 1980 & 1990 & 2000 & 1980 & 1990 \\
\hline \multicolumn{11}{|c|}{ West South Central } \\
\hline Arkansas & 50 & 49 & 50 & 47 & 50 & 50 & 49 & 50 & 45 & 47 \\
\hline Louisiana & 40 & 28 & 44 & 50 & 30 & 34 & 35 & 38 & 27 & 34 \\
\hline Oklahoma & 33 & 37 & 22 & 31 & 10 & 29 & 16 & 33 & 16 & 33 \\
\hline Texas & 38 & 35 & 31 & 33 & 36 & 32 & 32 & 46 & 24 & 20 \\
\hline \multicolumn{11}{|l|}{ Mountain } \\
\hline Montana & 25 & 22 & 13 & 32 & 28 & 23 & 12 & 25 & 12 & 18 \\
\hline Idaho & 22 & 36 & 43 & 43 & 26 & 28 & 40 & 49 & 7 & 36 \\
\hline Wyoming & 34 & 27 & 18 & 46 & 18 & 18 & 8 & 31 & 4 & 15 \\
\hline Colorado & 8 & 1 & 2 & 2 & 8 & 1 & 3 & 6 & 2 & 4 \\
\hline New Mexico & 32 & 17 & 30 & 36 & 14 & 8 & 17 & 23 & 17 & 11 \\
\hline Arizona & 23 & 18 & 20 & 40 & 13 & 13 & 28 & 41 & 15 & 17 \\
\hline Utah & 14 & 15 & 41 & 45 & 27 & 17 & 34 & 44 & 1 & 12 \\
\hline Nevada & 4 & 3 & 19 & 39 & 22 & 16 & 21 & 48 & 26 & 43 \\
\hline \multicolumn{11}{|l|}{$\overline{\text { Pacific }}$} \\
\hline Washington & 13 & 5 & 8 & 15 & 4 & 3 & 10 & 10 & 10 & 9 \\
\hline Oregon & 16 & 12 & 9 & 9 & 12 & 5 & 11 & 17 & 9 & 16 \\
\hline California & 5 & 7 & 17 & 18 & 7 & 10 & 22 & 16 & 5 & 6 \\
\hline Alaska & 20 & 11 & 4 & 23 & 3 & 2 & 1 & 11 & na & na \\
\hline Hawaii & 10 & 2 & 1 & 8 & 9 & 7 & 7 & 18 & na & na \\
\hline
\end{tabular}

information content vis-à-vis Mulligan and Sala-i-Martin's (2000) estimates. However, the rank correlations are much weaker between our state rankings and Mulligan and Sala-i-Martin's (1997) rankings based on a labor-income approach and lie in the 0.11 to 0.50 range.

Table 4 presents summary measures of state rankings based on ADF and ORG data. These results show that states with relatively high mean rankings (e.g., Connecticut, New York, Maryland, Colorado) tend to be in the upper half of the rankings in nearly all years. The states with relatively low mean rankings (e.g., South Dakota, Mississippi, Arkansas) tend to be in the lower half of the rankings in nearly all years. Those states with mean ranks in the middle tend to vary into the lower and the upper ranks over time (e.g., Vermont, Ohio, Minnesota). This suggests that there is substantial mixing in the distribution over time. As indicated by the difference between maximum and minimum rank, the mixing at the extremes can be quite substantial.

With the mixing that is apparent, an interesting question is whether there is a tendency towards convergence in the estimates. Table 5 presents the annualized growth rates of average human capital per worker for each state over the 1976-2000 period for the ADF data and 1979-2000 for the ORG data. For comparability, the 1979-2000 state growth rates based on the ADF data are also presented. The state rankings related to these growth rates are also reported. The difference in growth rates between the highest 
TABLE 4

Summary Measures of Rank by State for Alternative Current Population Survey Data Sets

\begin{tabular}{|c|c|c|c|c|c|c|c|c|c|c|c|c|c|c|}
\hline & \multicolumn{7}{|c|}{ Annual Demographic Files: 1976-2000 } & \multicolumn{7}{|c|}{ Outgoing Rotation Group Files: 1979-2000 } \\
\hline & \multirow[b]{2}{*}{$\begin{array}{l}\text { Mean } \\
\text { Rank }\end{array}$} & \multirow{2}{*}{$\begin{array}{c}\text { Std. } \\
\text { Dev. of } \\
\text { Rank }\end{array}$} & \multirow[b]{2}{*}{$\begin{array}{l}\text { Min } \\
\text { Rank }\end{array}$} & \multirow[b]{2}{*}{$\begin{array}{l}\text { Max } \\
\text { Rank }\end{array}$} & \multirow{2}{*}{$\begin{array}{c}\text { Max } \\
\text { less Min } \\
\text { Rank }\end{array}$} & \multicolumn{2}{|c|}{ Number of times } & \multirow[b]{2}{*}{$\begin{array}{l}\text { Mean } \\
\text { Rank }\end{array}$} & \multirow{2}{*}{$\begin{array}{c}\text { Std. } \\
\text { Dev. of } \\
\text { Rank }\end{array}$} & \multirow[b]{2}{*}{$\begin{array}{l}\text { Min. } \\
\text { Rank }\end{array}$} & \multirow[b]{2}{*}{$\begin{array}{l}\text { Max. } \\
\text { Rank }\end{array}$} & \multirow{2}{*}{$\begin{array}{c}\text { Max } \\
\text { less Min } \\
\text { Rank }\end{array}$} & \multicolumn{2}{|c|}{ Number of times } \\
\hline & & & & & & $\begin{array}{l}\text { Rank } \\
\leq 10\end{array}$ & $\begin{array}{l}\text { Rank } \\
\geq 41\end{array}$ & & & & & & $\begin{array}{l}\text { Rank } \\
\leq 10\end{array}$ & $\begin{array}{l}\text { Rank } \\
\geq 41\end{array}$ \\
\hline Maine & 31 & 9 & 9 & 44 & 35 & 1 & 4 & 31 & 6 & 19 & 42 & 23 & 0 & 1 \\
\hline New Hampshire & 16 & 10 & 3 & 41 & 38 & 8 & 1 & 16 & 8 & 8 & 37 & 29 & 9 & 0 \\
\hline Rhode Island & 26 & 13 & 3 & 48 & 45 & 4 & 4 & 29 & 11 & 7 & 47 & 40 & 1 & 4 \\
\hline Connecticut & 5 & 4 & 1 & 18 & 17 & 21 & 0 & 5 & 4 & 1 & 16 & 15 & 20 & 0 \\
\hline \multicolumn{15}{|c|}{ Middle Atlantic Division } \\
\hline New York & 7 & 2 & 3 & 12 & 9 & 23 & 0 & 8 & 2 & 4 & 10 & 6 & 22 & 0 \\
\hline New Jersey & 7 & 5 & 2 & 21 & 19 & 22 & 0 & 7 & 3 & 4 & 12 & 8 & 18 & 0 \\
\hline Illinois & 17 & 5 & 5 & 24 & 19 & 2 & 0 & 16 & 3 & 9 & 22 & 13 & 1 & 0 \\
\hline Michigan & 25 & 6 & 17 & 37 & 20 & 0 & 0 & 23 & 4 & 16 & 30 & 14 & 0 & 0 \\
\hline Wisconsin & 29 & 9 & 13 & 44 & 31 & 0 & 2 & 28 & 6 & 17 & 40 & 23 & 0 & 0 \\
\hline \multicolumn{15}{|c|}{ West North Central Division } \\
\hline Minnesota & 22 & 10 & 4 & 40 & 36 & 5 & 0 & 22 & 8 & 7 & 35 & 28 & 3 & 0 \\
\hline Iowa & 37 & 5 & 23 & 46 & 23 & 0 & 7 & 39 & 5 & 25 & 45 & 20 & 0 & 11 \\
\hline Missouri & 30 & 6 & 17 & 41 & 24 & 0 & 1 & 30 & 9 & 13 & 45 & 32 & 0 & 4 \\
\hline North Dakota & 39 & 8 & 21 & 49 & 28 & 0 & 13 & 38 & 7 & 20 & 46 & 26 & 0 & 10 \\
\hline South Dakota & 44 & 4 & 35 & 50 & 15 & 0 & 21 & 46 & 4 & 31 & 49 & 18 & 0 & 19 \\
\hline Nebraska & 35 & 7 & 18 & 46 & 28 & 0 & 5 & 36 & 6 & 19 & 46 & 27 & 0 & 3 \\
\hline
\end{tabular}




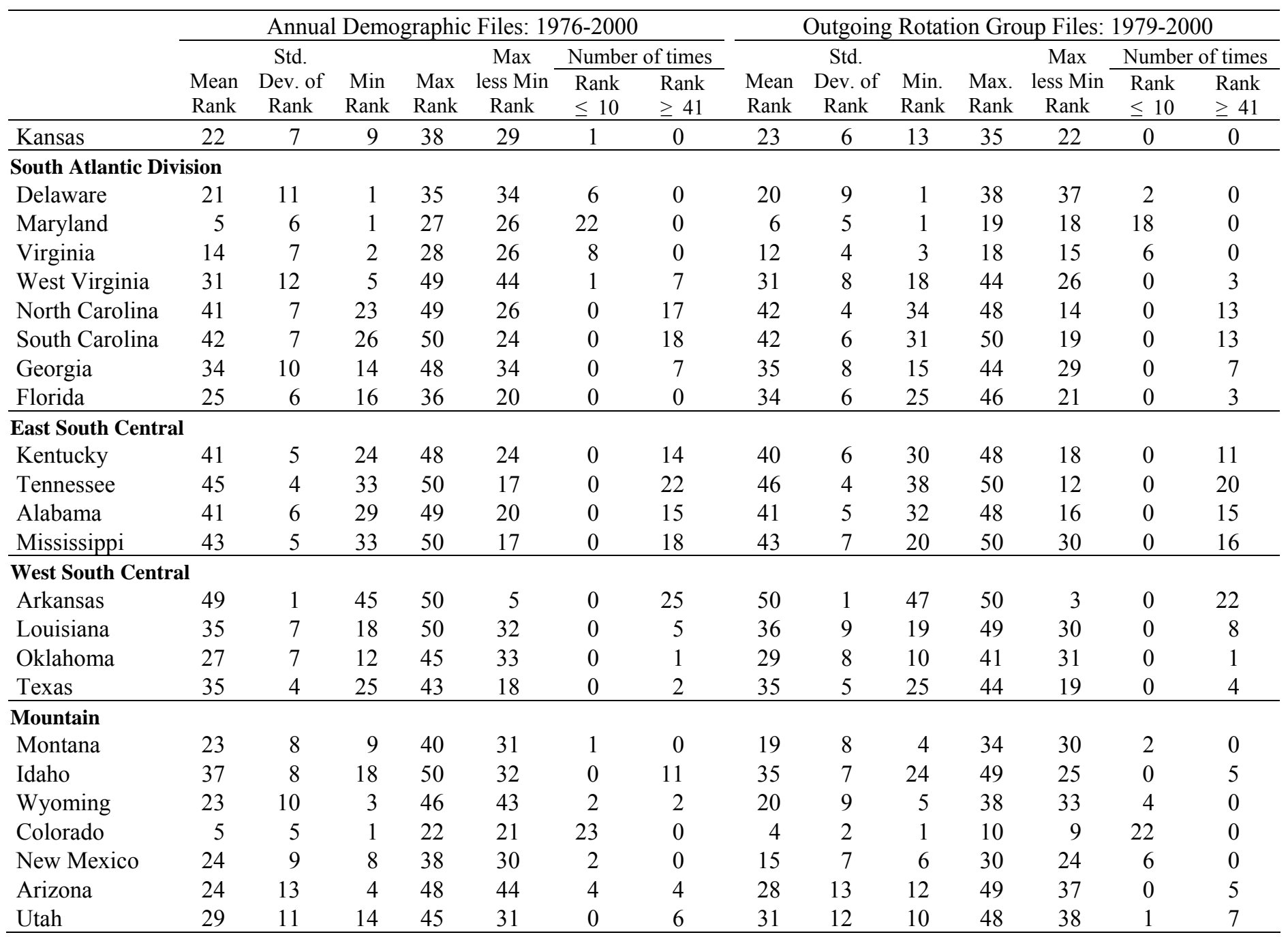




\begin{tabular}{|c|c|c|c|c|c|c|c|c|c|c|c|c|c|c|}
\hline & \multicolumn{7}{|c|}{ Annual Demographic Files: 1976-2000 } & \multicolumn{7}{|c|}{ Outgoing Rotation Group Files: 1979-2000 } \\
\hline & \multirow[b]{2}{*}{$\begin{array}{l}\text { Mean } \\
\text { Rank }\end{array}$} & \multirow{2}{*}{$\begin{array}{c}\text { Std. } \\
\text { Dev. of } \\
\text { Rank }\end{array}$} & \multirow[b]{2}{*}{$\begin{array}{c}\text { Min } \\
\text { Rank }\end{array}$} & \multirow[b]{2}{*}{$\begin{array}{l}\text { Max } \\
\text { Rank } \\
\end{array}$} & \multirow{2}{*}{$\begin{array}{c}\text { Max } \\
\text { less Min } \\
\text { Rank }\end{array}$} & \multicolumn{2}{|c|}{ Number of times } & \multirow[b]{2}{*}{$\begin{array}{l}\text { Mean } \\
\text { Rank }\end{array}$} & \multirow{2}{*}{$\begin{array}{c}\text { Std. } \\
\text { Dev. of } \\
\text { Rank }\end{array}$} & \multirow[b]{2}{*}{$\begin{array}{l}\text { Min. } \\
\text { Rank }\end{array}$} & \multirow[b]{2}{*}{$\begin{array}{l}\text { Max. } \\
\text { Rank }\end{array}$} & \multirow{2}{*}{$\begin{array}{c}\text { Max } \\
\text { less Min } \\
\text { Rank }\end{array}$} & \multicolumn{2}{|c|}{ Number of times } \\
\hline & & & & & & $\begin{array}{l}\text { Rank } \\
\leq 10\end{array}$ & $\begin{array}{l}\text { Rank } \\
\geq 41\end{array}$ & & & & & & $\begin{array}{l}\text { Rank } \\
\leq 10\end{array}$ & $\begin{array}{l}\text { Rank } \\
\geq 41\end{array}$ \\
\hline Nevada & 19 & 10 & 3 & 42 & 39 & 4 & 1 & 28 & 9 & 16 & 47 & 31 & 0 & 3 \\
\hline \multicolumn{15}{|l|}{ Pacific } \\
\hline Washington & 8 & 5 & 1 & 22 & 21 & 20 & 0 & 5 & 4 & 1 & 16 & 15 & 20 & 0 \\
\hline Oregon & 13 & 7 & 1 & 34 & 33 & 11 & 0 & 10 & 7 & 1 & 28 & 27 & 13 & 0 \\
\hline California & 11 & 5 & 4 & 22 & 18 & 13 & 0 & 13 & 4 & 7 & 21 & 14 & 7 & 0 \\
\hline Alaska & 12 & 9 & 1 & 36 & 35 & 14 & 0 & 5 & 4 & 1 & 11 & 10 & 18 & 0 \\
\hline Hawaii & 11 & 9 & 1 & 41 & 40 & 16 & 1 & 11 & 7 & 3 & 26 & 23 & 11 & 0 \\
\hline
\end{tabular}


TABLE 5

Annual Growth Rates of Estimated Human Capital per Worker by State with Rankings Using Annual Demographic and Outgoing Rotations Group Data File

\begin{tabular}{|c|c|c|c|c|c|c|}
\hline & \multicolumn{2}{|c|}{$\begin{array}{l}\text { Annual Demographic File Data } \\
\text { Annual Growth Rate (\%) }\end{array}$} & \multicolumn{2}{|c|}{$\begin{array}{l}\text { Outgoing Rotation Groups Data } \\
\text { Annual Growth Rate (\%) }\end{array}$} & \multicolumn{2}{|c|}{$\begin{array}{l}\text { Annual Demographic File Data } \\
\text { Annual Growth Rate }(\%)\end{array}$} \\
\hline & $1976-2000$ & Rank & 1979-2000 & Rank & 1979-2000 & Rank \\
\hline \multicolumn{7}{|c|}{ New England Division } \\
\hline Maine & 0.93 & 8 & 0.73 & 23 & 1.03 & 7 \\
\hline New Hampshire & 0.73 & 41 & 0.72 & 25 & 0.89 & 26 \\
\hline Vermont & 0.91 & 14 & 0.63 & 39 & 1.05 & 6 \\
\hline Massachusetts & 0.91 & 13 & 0.97 & 1 & 1.08 & 2 \\
\hline Rhode Island & 0.91 & 12 & 0.88 & 3 & 0.93 & 19 \\
\hline Connecticut & 0.93 & 11 & 0.78 & 14 & 0.99 & 10 \\
\hline \multicolumn{7}{|c|}{ Middle Atlantic Division } \\
\hline New York & 0.81 & 31 & 0.69 & 29 & 0.88 & 29 \\
\hline New Jersey & 0.90 & 15 & 0.82 & 7 & 0.97 & 11 \\
\hline Pennsylvania & 0.88 & 17 & 0.72 & 27 & 0.90 & 24 \\
\hline \multicolumn{7}{|c|}{ East North Central Division } \\
\hline Ohio & 0.74 & 40 & 0.68 & 31 & 0.77 & 40 \\
\hline Indiana & 0.79 & 34 & 0.85 & 5 & 1.06 & 4 \\
\hline Illinois & 0.81 & 30 & 0.64 & 38 & 0.91 & 23 \\
\hline Michigan & 0.82 & 27 & 0.73 & 22 & 0.88 & 30 \\
\hline Wisconsin & 0.84 & 24 & 0.75 & 19 & 0.95 & 15 \\
\hline \multicolumn{7}{|c|}{ West North Central Division } \\
\hline Minnesota & 0.93 & 9 & 0.82 & 8 & 1.14 & 1 \\
\hline Iowa & 0.87 & 19 & 0.81 & 9 & 1.00 & 9 \\
\hline Missouri & 0.85 & 22 & 0.79 & 11 & 0.93 & 18 \\
\hline North Dakota & 0.77 & 36 & 0.78 & 13 & 0.79 & 39 \\
\hline South Dakota & 0.89 & 16 & 0.88 & 2 & 1.02 & 8 \\
\hline Nebraska & 0.75 & 39 & 0.77 & 16 & 0.80 & 38 \\
\hline Kansas & 0.82 & 25 & 0.72 & 26 & 0.95 & 14 \\
\hline
\end{tabular}




\begin{tabular}{|c|c|c|c|c|c|c|}
\hline & \multicolumn{2}{|c|}{$\begin{array}{l}\text { Annual Demographic File Data } \\
\text { Annual Growth Rate }(\%)\end{array}$} & \multicolumn{2}{|c|}{$\begin{array}{l}\text { Outgoing Rotation Groups Data } \\
\text { Annual Growth Rate }(\%)\end{array}$} & \multicolumn{2}{|c|}{$\begin{array}{l}\text { Annual Demographic File Data } \\
\text { Annual Growth Rate }(\%)\end{array}$} \\
\hline & $1976-2000$ & Rank & 1979-2000 & Rank & 1979-2000 & Rank \\
\hline \multicolumn{7}{|c|}{ South Atlantic Division } \\
\hline Delaware & 0.53 & 48 & 0.52 & 47 & 0.70 & 45 \\
\hline Maryland & 0.82 & 26 & 0.76 & 18 & 0.93 & 17 \\
\hline Virginia & 1.08 & 1 & 0.81 & 10 & 1.08 & 3 \\
\hline West Virginia & 0.49 & 50 & 0.65 & 34 & 0.81 & 36 \\
\hline North Carolina & 0.99 & 6 & 0.78 & 12 & 0.83 & 35 \\
\hline South Carolina & 1.03 & 2 & 0.88 & 4 & 1.05 & 5 \\
\hline Georgia & 1.00 & 4 & 0.72 & 24 & 0.97 & 12 \\
\hline Florida & 0.86 & 21 & 0.74 & 21 & 0.94 & 16 \\
\hline \multicolumn{7}{|c|}{ East South Central } \\
\hline Kentucky & 0.81 & 28 & 0.67 & 32 & 0.92 & 20 \\
\hline Tennessee & 0.93 & 10 & 0.78 & 15 & 0.92 & 21 \\
\hline Alabama & 0.86 & 20 & 0.70 & 28 & 0.85 & 34 \\
\hline Mississippi & 1.02 & 3 & 0.76 & 17 & 0.86 & 33 \\
\hline \multicolumn{7}{|c|}{ West South Central } \\
\hline Arkansas & 0.99 & 5 & 0.84 & 6 & 0.95 & 13 \\
\hline Louisiana & 0.66 & 46 & 0.64 & 37 & 0.68 & 46 \\
\hline Oklahoma & 0.80 & 33 & 0.53 & 46 & 0.90 & 25 \\
\hline Texas & 0.81 & 29 & 0.65 & 35 & 0.89 & 28 \\
\hline \multicolumn{7}{|l|}{ Mountain } \\
\hline Montana & 0.75 & 38 & 0.69 & 30 & 0.87 & 32 \\
\hline Idaho & 0.66 & 45 & 0.48 & 50 & 0.80 & 37 \\
\hline Wyoming & 0.70 & 42 & 0.59 & 44 & 0.75 & 41 \\
\hline Colorado & 0.95 & 7 & 0.74 & 20 & 0.92 & 22 \\
\hline New Mexico & 0.75 & 37 & 0.62 & 40 & 0.66 & 49 \\
\hline Arizona & 0.67 & 43 & 0.49 & 49 & 0.66 & 48 \\
\hline Utah & 0.59 & 47 & 0.58 & 45 & 0.65 & 50 \\
\hline Nevada & 0.50 & 49 & 0.52 & 48 & 0.67 & 47 \\
\hline
\end{tabular}




\begin{tabular}{|c|c|c|c|c|c|c|}
\hline & \multicolumn{2}{|c|}{$\begin{array}{l}\text { Annual Demographic File Data } \\
\text { Annual Growth Rate }(\%)\end{array}$} & \multicolumn{2}{|c|}{$\begin{array}{l}\text { Outgoing Rotation Groups Data } \\
\text { Annual Growth Rate (\%) }\end{array}$} & \multicolumn{2}{|c|}{$\begin{array}{l}\text { Annual Demographic File Data } \\
\text { Annual Growth Rate }(\%)\end{array}$} \\
\hline & $1976-2000$ & Rank & $1979-2000$ & Rank & $1979-2000$ & Rank \\
\hline \multicolumn{7}{|l|}{ Pacific } \\
\hline Washington & 0.78 & 35 & 0.66 & 33 & 0.71 & 44 \\
\hline Oregon & 0.88 & 18 & 0.64 & 36 & 0.88 & 31 \\
\hline California & 0.67 & 44 & 0.60 & 43 & 0.75 & 42 \\
\hline Alaska & 0.80 & 32 & 0.62 & 41 & 0.74 & 43 \\
\hline Hawaii & 0.84 & 23 & 0.60 & 42 & 0.89 & 27 \\
\hline
\end{tabular}


and lowest for the common period 1979-2000 is 0.49 percentage points for both ADF and ORG. Based on ADF data, the maximum and minimum growth rates are 1.14 percent and 0.65 percent, respectively. Based on the ORG data, the maximum and minimum are 0.97 percent and 0.48 percent, respectively.

Using these growth rates, Table 6 presents convergence regressions, regressions of state average human capital per worker growth rates over the 1976-2000 period (ADF) and over the 1979-2000 period (ORG) on the corresponding beginning-of-period state average human capital per worker log levels. In addition, the regression results are also reported using data that are adjusted to remove the effects of the change of schooling variable definition discussed above. ${ }^{12}$ As the results show, removing the effect of the change in the definition of education produces very little difference in the estimates.

The conclusion from these convergence regressions is that the data are characterized by unconditional beta convergence as indicated by the statistically significant negative slope parameter estimate in the two regressions using the original ADF and ORG series. The overall rate of convergence is about two percent per year. At this rate, it would take more than one-third of a century to eliminate 50 percent of an initial gap in state average human capital per worker. The convergence rate for the two smoothed series is 1.8 percent per year, and therefore very close in magnitude to the estimates based on the original series. Consequently, it appears that the change in definition of the education variable does not have a substantial impact upon convergence estimates. In addition, it should be noted that the method used to smooth the series does not affect the ordinal structure of the data, and therefore the rank analyses are unaffected. Of course the smoothed series have growth rates over the 1976-2000 and 1979-2000 intervals that are somewhat lower than those for the original series. The rankings however are unaffected. ${ }^{13}$

\subsection{Aggregate Human Capital: Its Growth and Decomposition}

Adding the growth rate of average human capital per worker in a state to the growth rate of the scale of the state's workforce yields the growth rate of the state's aggregate

\footnotetext{
${ }^{12}$ The adjustment is done by using an analysis of varianace model to extract the discrete increase that occurs in the average human capital series in both the ADF and ORG data sets. Visual examination of the adjusted series, in contrast to the unadjusted series, indicates that this method successfully removes the discrete jump produced by the change in the education variable's definition in 1992 (impacting ADF data in 1991 and ORG data in 1992). The estimated discrete shift is about $0.35 \log$ points for the ADF series and about $0.37 \log$ points for the ORG series.

${ }^{13}$ The interpretation of the estimated parameter on log-level of initial per capita human capital as a good measure of the beta convergence rate potentially is problematic. As shown by Islam (1995), unobservable cross-section unit effects and the endogeneity of regressors can induce bias. Mismeasurement of initial income has been another problematic issue in the convergence literature, and this applies potentially to our estimates of per-worker human capital. In addition, we have 50 observations, and this could be viewed as a small sample leading to related sample-size bias (Caselli, Esquivel, Lefort 1996; Evans 1997; Quah 1996). So caution should be used in interpreting the estimates as strictly involving only a measurement of convergence speed.
} 
TABLE 6

Convergence of Average Human Capital Per Worker Across States in Two Alternative Data Files

\begin{tabular}{|c|c|c|c|c|c|c|}
\hline \multicolumn{7}{|c|}{ Annual Demographic File Estimates } \\
\hline \multirow[b]{3}{*}{ Variable } & \multicolumn{3}{|c|}{$\begin{array}{c}\text { Original Data } \\
\text { Growth Rate: } 1976-2000\end{array}$} & \multicolumn{3}{|c|}{$\begin{array}{c}\text { Smoothed Data } \\
\text { Growth Rate: } 1976-2000\end{array}$} \\
\hline & Estimated & Estimated & & Estimated & Estimated & \\
\hline & Parameter & $\underline{\text { Std. Error }}$ & p-value & Parameter & Std. Errol & p-value \\
\hline CONSTANT & 0.041 & 0.008 & 0.000 & 0.037 & 0.009 & 0.000 \\
\hline Log HKAVE76 & $\underline{-0.019}$ & $\underline{0.005}$ & $\underline{0.000}$ & $\underline{-0.018}$ & $\underline{0.005}$ & $\underline{0.001}$ \\
\hline R-Square & & 0.247 & & & 0.205 & \\
\hline F-Statistic & & 15.8 & & & 12.36 & \\
\hline (p-value) & & 0.000 & & & 0.001 & \\
\hline Number of observations & & 50 & & & 50 & \\
\hline
\end{tabular}

Outgoing Rotation Groups File Estimates

\begin{tabular}{|c|c|c|c|c|c|c|}
\hline \multirow[b]{3}{*}{ Variable } & \multicolumn{3}{|c|}{$\begin{array}{c}\text { Original Data } \\
\text { Growth Rate: } 1979-2000\end{array}$} & \multicolumn{3}{|c|}{$\begin{array}{c}\text { Smoothed Data } \\
\text { Growth Rate: } 1979-2000\end{array}$} \\
\hline & Estimated & Estimated & & Estimated & Estimated & \\
\hline & Parameter & Std. Error & $\mathrm{p}$-value & Parameter & $\underline{\text { Std. Error }}$ & p-value \\
\hline CONSTANT & 0.040 & 0.008 & 0.000 & 0.033 & 0.008 & 0.000 \\
\hline$\underline{\log \text { HKAVE79 }}$ & $\underline{-0.020}$ & $\underline{0.005}$ & $\underline{0.000}$ & $\underline{-0.018}$ & $\underline{0.005}$ & $\underline{0.001}$ \\
\hline R-Square & & 0.259 & & & 0.194 & \\
\hline F-Statistic & & 16.8 & & & 11.6 & \\
\hline (p-value) & & 0.000 & & & 0.001 & \\
\hline Number of observations & & 50 & & & 50 & \\
\hline
\end{tabular}

Notes: Dependent variable in each specification is growth rate $r$ in estimated average human capital per worker by state: $r=\ln [h(T) / h(0)] / T$. HKAVE76 = Estimated average human capital index per worker for each state in 1976. HKAVE79 = Estimated average human capital index per worker for each state in 1979. CONSTANT $=$ The intercept term of the model. Smoothed data indicates that the original dependent variable data have been adjusted to remove the effects of the change in the education variable's definition. See text for discussion. Estimation using the White HeteroskedasticityConsistent Standard Error method does not change the significance or magnitude of any results.

human capital. The ADF and ORG datasets on which we have relied to compute estimates of average per-worker human capital by state contain the necessary information to estimate the scale of each state's workforce by year. The two key variables are the number of workers in the sample for each state-year cell and the corresponding weights. The product of these two variables for each state-year cell gives an annual estimate of the workforce scale in each state. We have computed this product by gender and then summed to obtain annual estimates of workforce scale for each state and each of the four census regions. Average annual growth rates of scale over the 1976-2000 (ADF) and 1979-2000 (ORG) periods have been computed for each state and region. When added to the corresponding average annual growth rates for per-worker human capital, annual estimates of the growth rate of aggregate human capital by state are obtained. 
Table 7 presents these aggregate growth rates and their additive decomposition into scale and per-worker components. Relevant ranking information is also given in the table. The ADF- and the ORG-based estimates concur that the states with the highest growth rates in aggregate human capital in the last quarter of the twentieth century are Nevada, Arizona, and Florida. Moreover, Georgia and Utah are either ranked fourth or fifth. Three states consistently show up in the lowest five in aggregate human capital growth across both samples: Connecticut, West Virginia, and New York. Other states at the bottom of the aggregate growth rankings are Illinois, Montana, Pennsylvania, and Rhode Island

In terms of scale of workforce growth, both samples indicate that Nevada, Arizona, Florida, and Utah are the top four. Texas is ranked fifth in ADF, whereas Georgia is fifth in ORG. Only two states among the five with the lowest growth rates in scale Connecticut and New York - are common across the samples. Although there are some differences in the extremes of the distributions, the mean growth rate for scale is very similar across the samples: 2.40 percent (ADF) and 2.30 percent (ORG). Likewise, the standard deviations are similar: 0.82 (ADF) and 0.89 (ORG). The correlation of the state scale growth rate estimates between the two samples is 0.91; and the Spearman rank correlation is 0.95 . So, it appears that the ADF- and ORG-based estimates of the growth rates of workforce scale are quite comparable.

In terms of growth rates in average human capital per worker, there is only one state in common across the two samples in both the top five and bottom five rankings. In the top five, the common state is South Carolina; in the bottom five, the common one is Delaware. Although there are differences in the extremes of the distributions, the mean growth rate for average human capital per worker is similar across the samples: 0.82 percent (ADF) and 0.71 percent (ORG). Likewise, the standard deviations are similar: 0.13 (ADF) and $0.11(\mathrm{ORG})$. The correlation of the state growth rate estimates between the two samples is 0.69 , and the Spearman rank correlation is 0.68 . These correlations are lower than the corresponding ones for the growth rates of the state workforce scales; however, they are still relatively large and quite significant statistically. We may conclude that although the ADF- and ORG-based estimates of workforce scale growth rates are more comparable, the two samples produce similar growth rate estimates for average human capital per worker under our methodology.

Several interesting patterns appear in the decomposition. There is much more variation in the workforce scale component than in the per-worker component. The range of the former is from 0.51 percent (Connecticut) to 4.60 percent (Nevada), or 4.09 percentage points in the ADF-based estimates. For the later, the range is only 0.59 percentage points in the ADF-based estimates: from 0.49 percent (West Virginia) to 1.08 percent (Virginia). A similar contrast appears in the ORG-based estimates. A correlation analysis reveals that there is a systematic negative relationship between the two components. The correlation between the growth rate in workforce scale and average human capital per worker across the 50 states is -0.30 (ADF) and -0.46 (ORG). Both are statistically significant at conventional levels. In terms of rank ordering, the two components are also 
TABLE 7

Average Annualized Growth Rates of Total Human Capital by State and Census Region: Total, Scale, and Per Worker

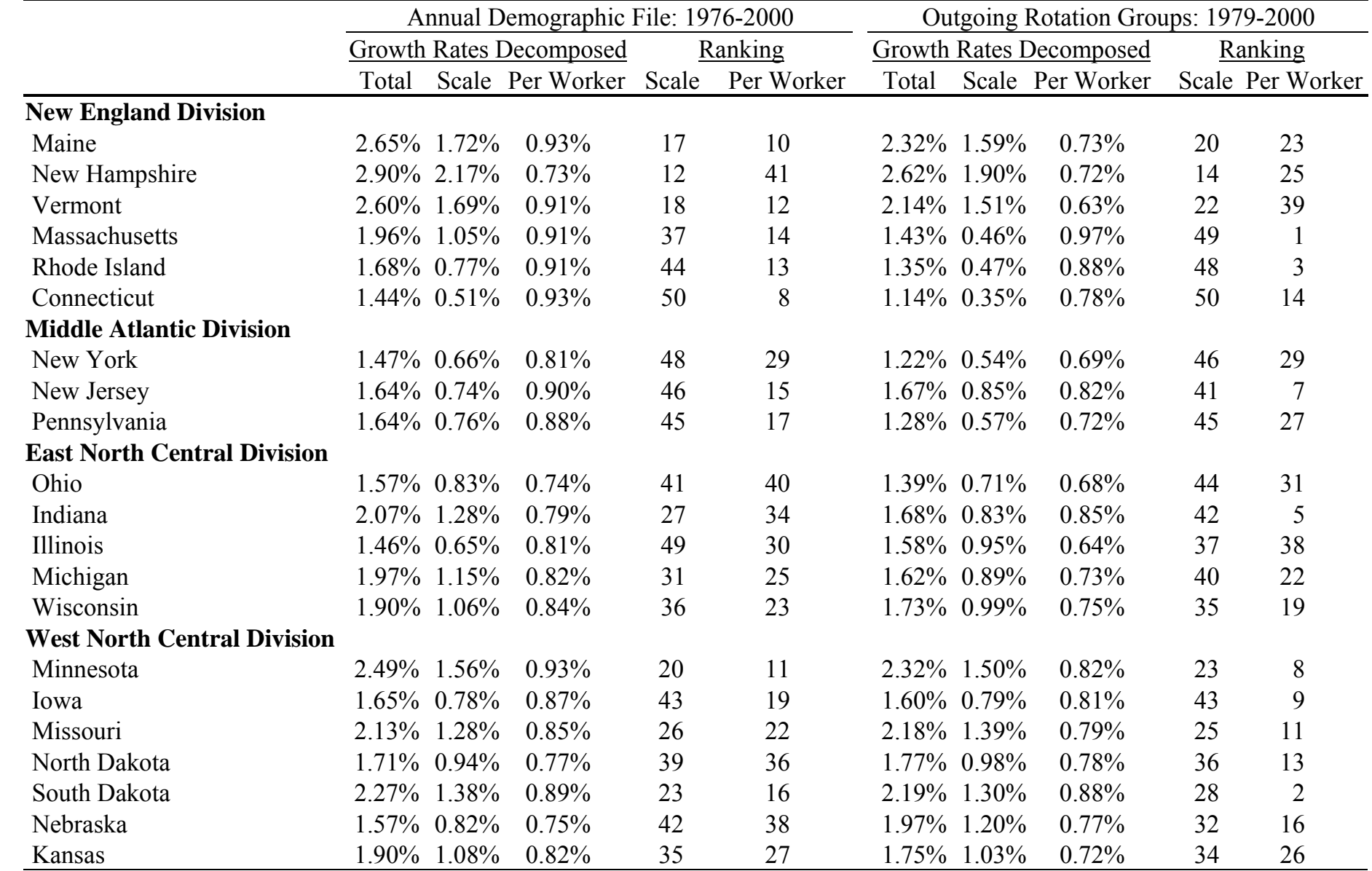




\begin{tabular}{|c|c|c|c|c|c|c|c|c|c|c|}
\hline & \multicolumn{5}{|c|}{ Annual Demographic File: 1976-2000 } & \multicolumn{5}{|c|}{ Outgoing Rotation Groups: 1979-2000 } \\
\hline & \multicolumn{3}{|c|}{ Growth Rates Decomposed } & \multicolumn{2}{|c|}{ Ranking } & \multicolumn{3}{|c|}{ Growth Rates Decomposed } & \multicolumn{2}{|c|}{ Ranking } \\
\hline & Total & Scale & Per Worker & Scale & Per Worker & Total & Scale & Per Worker & Scale & Per Worker \\
\hline \multicolumn{11}{|c|}{ South Atlantic Division } \\
\hline Delaware & $2.43 \%$ & $1.90 \%$ & $0.53 \%$ & 14 & 48 & $2.41 \%$ & $1.89 \%$ & $0.52 \%$ & 15 & 47 \\
\hline Maryland & $2.01 \%$ & $1.19 \%$ & $0.82 \%$ & 29 & 26 & $2.02 \%$ & $1.27 \%$ & $0.76 \%$ & 29 & 18 \\
\hline Virginia & $2.52 \%$ & $1.44 \%$ & $1.08 \%$ & 22 & 1 & $2.66 \%$ & $1.86 \%$ & $0.81 \%$ & 16 & 10 \\
\hline West Virginia & $1.41 \%$ & $0.92 \%$ & $0.49 \%$ & 40 & 50 & $1.16 \%$ & $0.51 \%$ & $0.65 \%$ & 47 & 34 \\
\hline North Carolina & $2.87 \%$ & $1.88 \%$ & $0.99 \%$ & 15 & 5 & $2.58 \%$ & $1.80 \%$ & $0.78 \%$ & 18 & 12 \\
\hline South Carolina & $2.40 \%$ & $1.37 \%$ & $1.03 \%$ & 24 & 2 & $2.88 \%$ & $2.00 \%$ & $0.88 \%$ & 13 & 4 \\
\hline Georgia & $3.45 \%$ & $2.45 \%$ & $1.00 \%$ & 8 & 4 & $3.49 \%$ & $2.77 \%$ & $0.72 \%$ & 5 & 24 \\
\hline Florida & $4.28 \%$ & $3.42 \%$ & $0.86 \%$ & 3 & 21 & $4.07 \%$ & $3.33 \%$ & $0.74 \%$ & 3 & 21 \\
\hline \multicolumn{11}{|c|}{ East South Central } \\
\hline Kentucky & $2.08 \%$ & $1.27 \%$ & $0.81 \%$ & 28 & 28 & $2.05 \%$ & $1.38 \%$ & $0.67 \%$ & 26 & 32 \\
\hline Tennessee & $2.49 \%$ & $1.56 \%$ & $0.93 \%$ & 21 & 9 & $2.48 \%$ & $1.69 \%$ & $0.78 \%$ & 19 & 15 \\
\hline Alabama & $2.01 \%$ & $1.15 \%$ & $0.86 \%$ & 32 & 20 & $2.18 \%$ & $1.48 \%$ & $0.70 \%$ & 24 & 28 \\
\hline Mississippi & $2.15 \%$ & $1.13 \%$ & $1.02 \%$ & 33 & 3 & $2.30 \%$ & $1.54 \%$ & $0.76 \%$ & 21 & 17 \\
\hline \multicolumn{11}{|c|}{ West South Central } \\
\hline Arkansas & $2.63 \%$ & $1.64 \%$ & $0.99 \%$ & 19 & 6 & $2.21 \%$ & $1.37 \%$ & $0.84 \%$ & 27 & 6 \\
\hline Louisiana & $1.68 \%$ & $1.02 \%$ & $0.66 \%$ & 38 & 46 & $1.53 \%$ & $0.89 \%$ & $0.64 \%$ & 38 & 37 \\
\hline Oklahoma & $1.98 \%$ & $1.18 \%$ & $0.80 \%$ & 30 & 33 & $1.76^{\circ}$ & $1.23 \%$ & $0.53 \%$ & 31 & 46 \\
\hline Texas & $3.33 \%$ & $2.52 \%$ & $0.81 \%$ & 5 & 31 & $3.04 \%$ & $2.39 \%$ & $0.65 \%$ & 9 & 35 \\
\hline \multicolumn{11}{|l|}{ Mountain } \\
\hline Montana & $1.48 \%$ & $0.73 \%$ & $0.75 \%$ & 47 & 37 & $1.92 \%$ & $1.24 \%$ & $0.69 \%$ & 30 & 30 \\
\hline Idaho & $3.02 \%$ & $2.36 \%$ & $0.66 \%$ & 9 & 45 & $2.69 \%$ & $2.21 \%$ & $0.48 \%$ & 10 & 50 \\
\hline Wyoming & $1.79 \%$ & $1.09 \%$ & $0.70 \%$ & 34 & 42 & $1.63 \%$ & $1.04 \%$ & $0.59 \%$ & 33 & 44 \\
\hline Colorado & $2.75 \%$ & $1.80 \%$ & $0.95 \%$ & 16 & 7 & $3.19 \%$ & $2.45 \%$ & $0.74 \%$ & 8 & 20 \\
\hline New Mexico & $2.94 \%$ & $2.19 \%$ & $0.75 \%$ & 11 & 39 & $2.80 \%$ & $2.18 \%$ & $0.62 \%$ & 11 & 40 \\
\hline Arizona & $4.41 \%$ & $3.74 \%$ & $0.67 \%$ & 2 & 44 & $4.42 \%$ & $3.92 \%$ & $0.49 \%$ & 2 & 49 \\
\hline Utah & $3.43 \%$ & $2.84 \%$ & $0.59 \%$ & 4 & 47 & $3.68 \%$ & $3.11 \%$ & $0.58 \%$ & 4 & 45 \\
\hline Nevada & $5.10 \%$ & $4.60 \%$ & $0.50 \%$ & 1 & 49 & $5.56 \%$ & $5.05 \%$ & $0.52 \%$ & 1 & 48 \\
\hline
\end{tabular}




\begin{tabular}{|c|c|c|c|c|c|c|c|c|c|c|}
\hline & \multicolumn{5}{|c|}{ Annual Demographic File: 1976-2000 } & \multicolumn{5}{|c|}{ Outgoing Rotation Groups: 1979-2000 } \\
\hline & \multicolumn{3}{|c|}{ Growth Rates Decomposed } & \multicolumn{2}{|c|}{ Ranking } & \multicolumn{3}{|c|}{ Growth Rates Decomposed } & \multicolumn{2}{|c|}{ Ranking } \\
\hline & Total & Scale & Per Worker & Scale & Per Worker & Total & Scale & Per Worker & Scale & Per Worker \\
\hline \multicolumn{11}{|c|}{ - } \\
\hline Washington & $3.30 \%$ & $2.52 \%$ & $0.78 \%$ & 7 & 35 & $3.20 \%$ & $2.54 \%$ & $0.66 \%$ & 7 & 33 \\
\hline Oregon & $2.99 \%$ & $2.11 \%$ & $0.88 \%$ & 13 & 18 & $2.45 \%$ & $1.81 \%$ & $0.64 \%$ & 17 & 36 \\
\hline California & $2.88 \%$ & $2.21 \%$ & $0.67 \%$ & 10 & 43 & $2.67 \%$ & $2.07 \%$ & $0.60 \%$ & 12 & 43 \\
\hline Alaska & $3.32 \%$ & $2.52 \%$ & $0.80 \%$ & 6 & 32 & $3.27 \%$ & $2.66 \%$ & $0.62 \%$ & 6 & 41 \\
\hline Hawaii & $2.17 \%$ & $1.33 \%$ & $0.84 \%$ & 25 & 24 & $1.49 \%$ & $0.89 \%$ & $0.60 \%$ & 39 & 42 \\
\hline \multicolumn{11}{|c|}{ Census Region } \\
\hline Northeast & $1.70 \%$ & $0.80 \%$ & $0.90 \%$ & & & $1.40 \%$ & $0.60 \%$ & $0.80 \%$ & & \\
\hline Midwest & $1.80 \%$ & $1.00 \%$ & $0.80 \%$ & & & $1.70 \%$ & $0.90 \%$ & $0.80 \%$ & & \\
\hline South & $2.80 \%$ & $2.00 \%$ & $0.80 \%$ & & & $2.80 \%$ & $2.00 \%$ & $0.80 \%$ & & \\
\hline West & $3.00 \%$ & $2.30 \%$ & $0.70 \%$ & & & $2.90 \%$ & $2.30 \%$ & $0.60 \%$ & & \\
\hline
\end{tabular}


These two main features of the decomposition can be easily seen in the bottom of Table 7 where the results are presented for census regions. First, it is clear that the workforce scale component is a much larger component of aggregate human capital growth than the per-worker component. Second, there is a tendency for the scale growth rates and per-worker growth rates to be inversely related. The regional results show in summary fashion that spatial differences in aggregate human capital growth rates in the last quarter of the twentieth century have been primarily due to spatial differences in the growth rate of workforce scale rather than spatial differences in average human capital accumulation rates per worker. Consistent with what is well known for other measures of regional growth over this time period, the results presented in Table 7 show the dramatic differences in the growth of aggregate human capital in the south and west regions of the U.S. These differences are due primarily to differences in the growth of workforce scales. Differences in growth rate of average human capital per worker actually slightly favor the northeast and midwest regions. However, this latter advantage for these regions is very small relative to the very large differences in workforce scale growth rates.

\section{SUMMARY AND CONCLUSIONS}

We have developed annual estimates of average human capital per worker by state for the period 1976-2000 using two CPS samples. The model underlying these estimates is a generalized Mincerian wage equation that separately specifies flow-price and quantity components. Flow-price variations depend on state, year, and demographic and employment characteristics. Quantity variations depend on nonlinear effects of schooling and potential experience. The relationship between our model and an alternative one developed by Mulligan and Sala-i-Martin (2000) is discussed. The state estimates of average human capital per worker from both studies for the years 1979 and 1989 are empirically compared using Spearman rank-correlation analysis and found to have substantial commonality of information content. Rank correlations are relatively weak between our estimates and earlier ones by Mulligan and Sala-i-Martin (1997).

The estimates based on the ADF and ORG are found to be highly correlated both at the interval and ordinal levels. Both sets of estimates indicate that top- (bottom-) ranked states tended to remain in the upper (lower) part of the spatial distribution of average human capital per worker during the last quarter of the twentieth century. States in the middle ranks shifted rankings more, implying that there was substantial mixing in the spatial distribution. Notwithstanding this mixing phenomenon, unconditional beta convergence was found to hold for both samples over their entire spans with the original and the smoothed data. The rates of convergence are highly statistically different from zero and range from just under two percent to nearly five percent per year. These rates imply that half of the gap between the common interstate steady-state value of human capital per worker and a state's current value would be eliminated over a period of 15 to 
38 years. This rate of convergence is somewhat higher than that reported in other studies of the United States. ${ }^{14}$

The ADF and ORG datasets also permit us to estimate aggregate human capital by state and year as well as its decomposition into workforce scale and per-worker components. The results for workforce scale are quite comparable across the two datasets. There is striking evidence of relatively large gains for southern and western states in comparison to northern and eastern states. This contrasts to the growth rates in perworker human capital, which show only a very small advantage for the latter states.

Aggregate human capital growth among the states in the last quarter of the twentieth century was dominated by scale of workforce trends that strongly favored southern and western states. Per-worker human capital growth displayed much narrower interstate variation during this period and exhibited unconditional beta convergence at a rate of about two percent per year on average.

\section{REFERENCES}

Barro, R.J. and X. Sala-i-Martin, 1998. Economic Growth. MIT Press: Cambridge, MA. Beeson, P.E. and R.W. Eberts, 1989. "Identifying Productivity and Amenity Effects in Interurban Wage Differentials," The Review of Economics and Statistics 71, 443-452.

Bils, M. and P.J. Klenow, 2000. "Does Schooling Cause Growth?" American Economic Review 90, 1160-1183.

Bellante, D., 1979. "The North-South Differential and the Migration of Heterogeneous Labor," American Economic Review 69, 166-175.

Bellante, D. and J.A. Dunlevy, 1983. "Net Migration, Endogenous Incomes and the Speed of Adjustment of the North-South Differential," The Review of Economics and Statistics 65, 66-75.

Belman, D. and J.S. Heywood, 1991. "Sheepskin Effects in the Returns to Education: An Examination of Women and Minorities," The Review of Economics and Statistics 73, 720-724.

Caselli, F., G. Esquivel, and F. LeFort, 1996. "Reopening the Convergence Debate: A New Look at Cross-Country Growth Empirics," Journal of Economic Growth 1, 363-389.

Evans, P., 1997. "How Fast Do Economies Converge?" Review of Economics and Statistics $36,219-225$

Greenwood, M.J., G.L. Hunt, and U. Kohli, 1997. "The Factor-Market Consequences of Unskilled Immigration to the United States," Labour Economics 4, 1-28.

Hall, R.E. and C.I. Jones, 1999. "Why Do Some Countries Produce So Much More Output Per Worker Than Others?" Quarterly Journal of Economics 114, 83-116.

\footnotetext{
${ }^{14}$ The comparable rate of convergence reported by Barro and Sala-i-Martin (1998; Table 11.1) for per capita income is approximately 1.7 percent per year. The rate of convergence in per-worker human capital reported by Mulligan and Sala-i-Martin (2000) is about one percent per year.
} 
Horiba, Y. and R.C. Kirkpatrick, 1979. "Labor Skills, Human Capital, and the Pattern of U.S. Interregional Trade," in William C. Wheaton (ed.), Interregional Movements and Regional Growth. The Urban Institute: Washington, D.C. , 1981. "Factor Endowments, Factor Proportions, and the Allocative Efficiency of U.S. Interregional Trade," The Review of Economics and Statistics 63, 178-187.

Hungerford, T. and G. Solon, 1987. "Sheepskin Effects in the Return to Education," The Review of Economic and Statistics 69, 175-177.

Jaeger, D.A. and M.E. Page, 1996. "Degrees Matter: New Evidence on Sheepskin Effects in the Returns to Education," The Review of Economics and Statistics 78, 733-740.

Jones, C.I., 2002. "Sources of U.S. Economic Growth in a World of Ideas," American Economic Review 92, 220-239.

Mincer, J., 1974. Schooling, Experience and Earnings. Columbia University Press for the National Bureau of Economic Research: New York.

Mulligan, C.B. and X. Sala-i-Martin, 1997. "A Labor Income Based Measure of Human Capital," Japan and the World Economy 9, 159-191. , 2000. "Measuring Aggregate Human Capital," Journal of Economic Growth 5, 215-252.

Murphy, K. and F. Welch, 1990. "Empirical Age-Earnings Profiles," Journal of Labor Economics 8, 202-229.

Quah, D.T., 1996. "Empirics for Economic Growth and Convergence," European Economic Review 40, 1453-1375.

Roback, J., 1982. "Wages, Rents, and the Quality of Life," Journal of Political Economy 90,1257-1278.

Rosen, S., 1992. "Mincering Labor Economics," Journal of Economic Perspectives 6, 157-170. 
APPENDIX TABLE

Implied Marginal Returns to Education

\begin{tabular}{|c|c|c|c|c|c|c|c|c|}
\hline \multirow{3}{*}{$\begin{array}{l}\text { Year of Schooling/ } \\
\text { Credential } \\
1\end{array}$} & \multicolumn{4}{|c|}{ Annual Demographic File } & \multicolumn{4}{|c|}{ Outgoing Rotations Groups } \\
\hline & \multicolumn{2}{|c|}{ Women } & \multicolumn{2}{|c|}{ Men } & \multicolumn{2}{|c|}{ Women } & \multicolumn{2}{|r|}{ Men } \\
\hline & 0.176 & 0.068 & 0.144 & 0.041 & 0.327 & 0.040 & 0.229 & 0.022 \\
\hline 2 & 0.130 & 0.068 & 0.128 & 0.040 & 0.025 & 0.039 & 0.020 & 0.022 \\
\hline 3 & -0.033 & 0.037 & 0.033 & 0.026 & -0.032 & 0.021 & 0.039 & 0.014 \\
\hline 4 & 0.068 & 0.028 & 0.058 & 0.022 & 0.087 & 0.016 & 0.067 & 0.012 \\
\hline 5 & 0.049 & 0.025 & 0.074 & 0.021 & 0.009 & 0.013 & 0.060 & 0.011 \\
\hline 6 & 0.020 & 0.019 & 0.039 & 0.016 & 0.034 & 0.010 & 0.029 & 0.008 \\
\hline 7 & 0.053 & 0.015 & 0.055 & 0.013 & 0.037 & 0.008 & 0.077 & 0.006 \\
\hline 8 & 0.058 & 0.013 & 0.097 & 0.010 & 0.060 & 0.007 & 0.070 & 0.005 \\
\hline 9 & 0.046 & 0.008 & 0.061 & 0.007 & 0.026 & 0.004 & 0.045 & 0.003 \\
\hline 10 & 0.065 & 0.007 & 0.075 & 0.006 & 0.061 & 0.003 & 0.063 & 0.003 \\
\hline 11 & 0.042 & 0.005 & 0.051 & 0.005 & 0.044 & 0.003 & 0.046 & 0.002 \\
\hline 12 & 0.180 & 0.004 & 0.178 & 0.004 & 0.154 & 0.002 & 0.140 & 0.002 \\
\hline 13 & 0.104 & 0.004 & 0.082 & 0.004 & 0.094 & 0.002 & 0.073 & 0.002 \\
\hline 14 & 0.082 & 0.005 & 0.064 & 0.005 & 0.092 & 0.002 & 0.067 & 0.002 \\
\hline 15 & 0.077 & 0.007 & 0.034 & 0.007 & 0.053 & 0.003 & 0.026 & 0.004 \\
\hline 16 & 0.117 & 0.007 & 0.204 & 0.007 & 0.144 & 0.003 & 0.199 & 0.004 \\
\hline 17 & 0.080 & 0.007 & 0.003 & 0.007 & 0.079 & 0.003 & 0.014 & 0.004 \\
\hline 18 & 0.225 & 0.009 & 0.232 & 0.009 & 0.219 & 0.004 & 0.186 & 0.005 \\
\hline $1-4(0)$ & 0.294 & 0.037 & 0.319 & 0.028 & 0.283 & 0.023 & 0.266 & 0.015 \\
\hline $5-6(1-4)$ & 0.124 & 0.022 & 0.168 & 0.020 & 0.121 & 0.014 & 0.158 & 0.010 \\
\hline $7-8(5-6)$ & 0.081 & 0.017 & 0.134 & 0.014 & 0.120 & 0.009 & 0.135 & 0.007 \\
\hline $9(7-8)$ & 0.090 & 0.013 & 0.093 & 0.011 & 0.069 & 0.006 & 0.103 & 0.006 \\
\hline 12 - No Diploma (11) & 0.060 & 0.013 & 0.009 & 0.013 & 0.014 & 0.006 & 0.009 & 0.006 \\
\hline H.S. Grad. (12 - ND) & 0.120 & 0.013 & 0.169 & 0.013 & 0.139 & 0.006 & 0.131 & 0.006 \\
\hline Some College (HS) & 0.143 & 0.004 & 0.152 & 0.004 & 0.130 & 0.002 & 0.119 & 0.002 \\
\hline Assoc. Degree - Voc. (HS) & 0.240 & 0.006 & 0.162 & 0.005 & 0.243 & 0.003 & 0.159 & 0.003 \\
\hline Assoc. Degree - Acad. (HS) & 0.296 & 0.006 & 0.225 & 0.007 & 0.268 & 0.003 & 0.188 & 0.004 \\
\hline Bachelor's Degree (HS) & 0.495 & 0.004 & 0.473 & 0.004 & 0.487 & 0.002 & 0.442 & 0.002 \\
\hline Master's Degree (BD) & 0.094 & 0.006 & 0.027 & 0.006 & 0.091 & 0.003 & 0.032 & 0.003 \\
\hline Professional Degree (BD) & 0.395 & 0.018 & 0.478 & 0.014 & 0.319 & 0.010 & 0.253 & 0.007 \\
\hline Doctoral (BD) & 0.344 & 0.020 & 0.302 & 0.014 & 0.309 & 0.012 & 0.236 & 0.007 \\
\hline
\end{tabular}

